J. Perinat. Med.

13 (1985) 287

\title{
Pelvimetry by digital radiography and its dosimetry
}

\author{
C. Claussen, D. Köhler, F. Christ*, G. Golde, B. Lochner
}

Departments of Radiology, (Director: Prof. Dr. R. Felix) and *Obstetrics and Gynecology (Director: Prof. Dr. G. Kindermann) University Hospitals Charlottenburg, Free University of Berlin, Fed. Rep. Germany

\section{Introduction}

Since the introduction of sonography into obstetrical diagnostic methods fetus and placenta can be measured and localized without exposure to radiation. However, the questions whether pelvic dimensions are adequate for the passage of an infant or whether there is a mechanical obstruction have not been satisfactorily answered by ultrasound which has not achieved the accuracy of $x$-ray pelvimetry $[1,12,13]$.

The principal disadvantage of conventional radiography lies in its relatively high radiation dose. Digital radiography, an accessory to all modern computer tomographs, offers an alternative.

\section{Methods}

Computer tomographic equipment of the third and fourth generations has an additional program which allows the acquisition of digital radiographs. They are chiefly needed to localize the suitable transverse cut.

With digital radiography summation images correlating to the conventional radiograph are obtained. During the exposure for the digital radiograph tube and detector of the computer tomograph remain stationary while the patient is moved along the long axis of her body. The variable positions of the image generating ( $x$ -

\section{Curriculum vitae}

Claus Claussen, born 1945 in Hameln, Germany. Medical School in Erlangen and Heidelberg. Graduation Heidelberg 1971. Radiology Residency, University of Heidelberg: Board Certification in Radiology 1978. Since 1979 on the staff of the Department of Radiology, Charlottenburg University Hos-

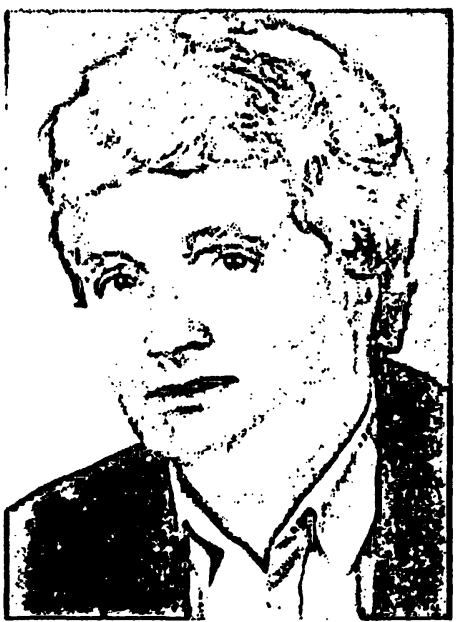
pitals, Free University of Berlin. Areas of interest: Dynamic computer tomography, nuclear magnetic resonance tomography.

ray tube) and image processing (detectors) components in relation to the long body axis allow a. -p., p. -a., and lateral projections on the recumbent patient. By a mathematical image reconstruction process a large spectrum of attenuation values is obtained and made visible on a television monitor in a 20 -step gray scale.

Integrated software allows direct measurement of the distance between any two points. By manipulating the gray scale, bony contours can be shown on the screen which do not show up as clearly on the subsequently obtained hard copy of the radiograph because of its lesser sensitivity. Because of the central projection, there is a position-dependent distortion for 
measurements at right angles to the movement of the topogram ("topogram" is the manufacturer's designation for the accessory equipment for digital radiography). We determined experimentally a formula to correct this scale distortion.

We used third generation computer tomography equipment (Somatom 2, Siemens). On patients in the supine position we obtained AP and lateral topograms.

\section{Radiation dose}

HüBENER [4] and FederLe et al. [2] indicate as skin dose for digital radiography a maximal entry dose of $100 \mathrm{mrad}\left(1.0 \times 10^{-3} \mathrm{~Gy}\right)$ and a skin exit dose of less than $10 \mathrm{mrad}\left(10^{-4} \mathrm{~Gy}\right)$. FEDERLE et al. obtained an absorption dose of $22 \mathrm{mrad}\left(2.2 \times 10^{-4} \mathrm{~Gy}\right)$. These values differ from those obtained by us on the Somatom 2 on a $30 \mathrm{~cm}$ wax phantom simulating absorption properties of human body tissue. We used ionisation dosimeters. For a topogram length of $256 \mathrm{~mm}$ the computer selected $80 \mathrm{mAs}$ and $125 \mathrm{kV}$. We found a skin entry dose of $153 \mu \mathrm{Gy}$
$(15.3 \mathrm{mrad})$ and an exit dose of $3.6 \mu \mathrm{Gy}$. In the center at $15 \mathrm{~cm}$ depth $24 \mu \mathrm{Gy}(2.4 \mathrm{mrad})$ were measured. Thus, a radiation dose of about $48 \mu \mathrm{Gy}(4.8 \mathrm{mrad})$ exists for the fetus because a lateral and a.-p. topogram were obtained in each case.

In addition, we measured radiation doses with high amplifying screens for comparison $[3,6$, 9]. We used a Quanta III screen (Dupont) and a Cronex IV (Dupont) film. The phantom measurements at $125 \mathrm{kV}$ and $4.5 \mathrm{mAs}$ (filter 0.1 $\mathrm{Cu} 1 \mathrm{Al})$ showed a sufficient skeletal image. The skin entry dose was $750 \mu \mathrm{Gy}$ ( $75 \mathrm{mrad})$. The exit dose was $17 \mu \mathrm{Gy}$. In the center a dose of $177 \mu \mathrm{Gy}$ was measured. In our experience these values are optimal for conventional pelvimetry. In comparison the radiation dose for digital radiography is 7 times less.

\section{Patients and indications}

From May 1982 to October 1983 twenty-five pregnant women underwent digital pelvimetry. The following dimensions were determined: transverse (Fig. 1) and obstetric conjugate

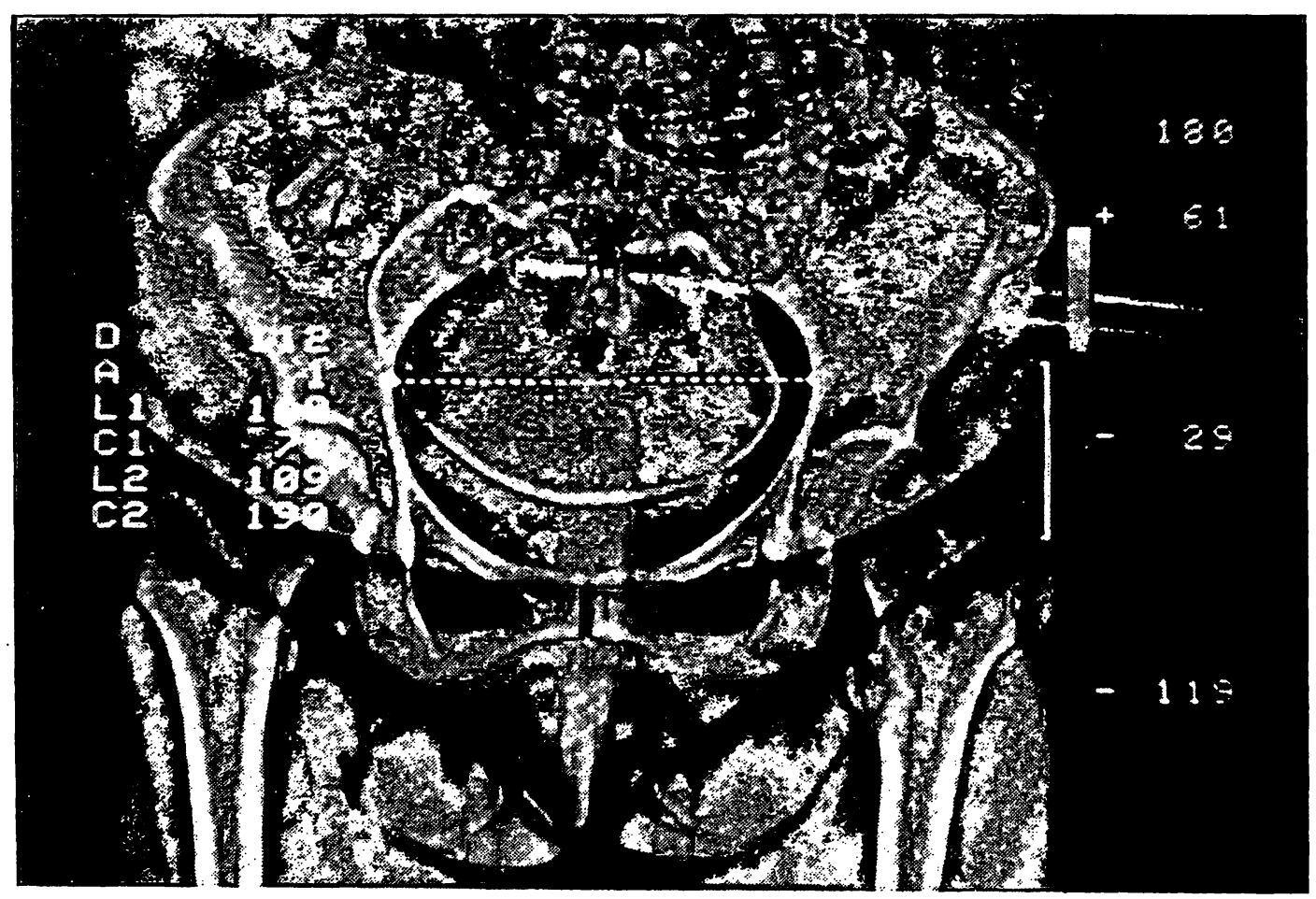

Fig. 1. Transverse diameter $\mathrm{D}=11.2 \mathrm{~cm}$ (normal $13.5 \mathrm{~cm}$ ); corrected distance $11.5 \mathrm{~cm}$ (The correction resulted from the formula determined by us). 
diameters (Fig. 2) as the two most important measurements and the interspinous diameter (Fig. 3) as the measurement for the narrowest part of the pelvis. Other measurements such as the oblique diameters of the pelvic inlet, the diagonal conjugate (promontory to lower rim of symphysis) or the distance from the tip of the coccyx to the lower rim of the symphysis

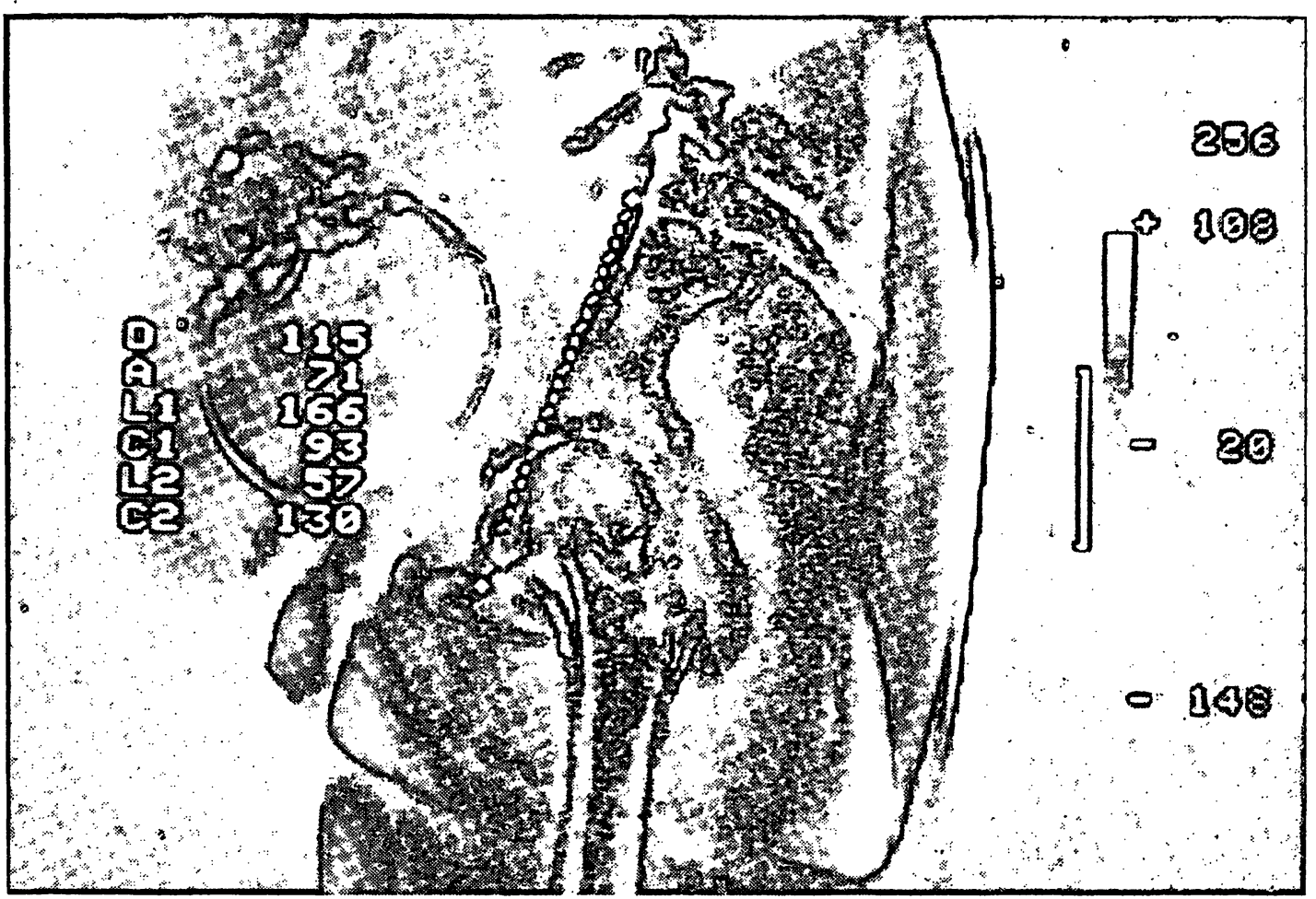

Fig. 2. Obstetric conjugate diameter. $\mathrm{D}=11.5 \mathrm{~cm}$, (normal $11 \mathrm{~cm}$ ). No correction necessary because the error is neglibly small.

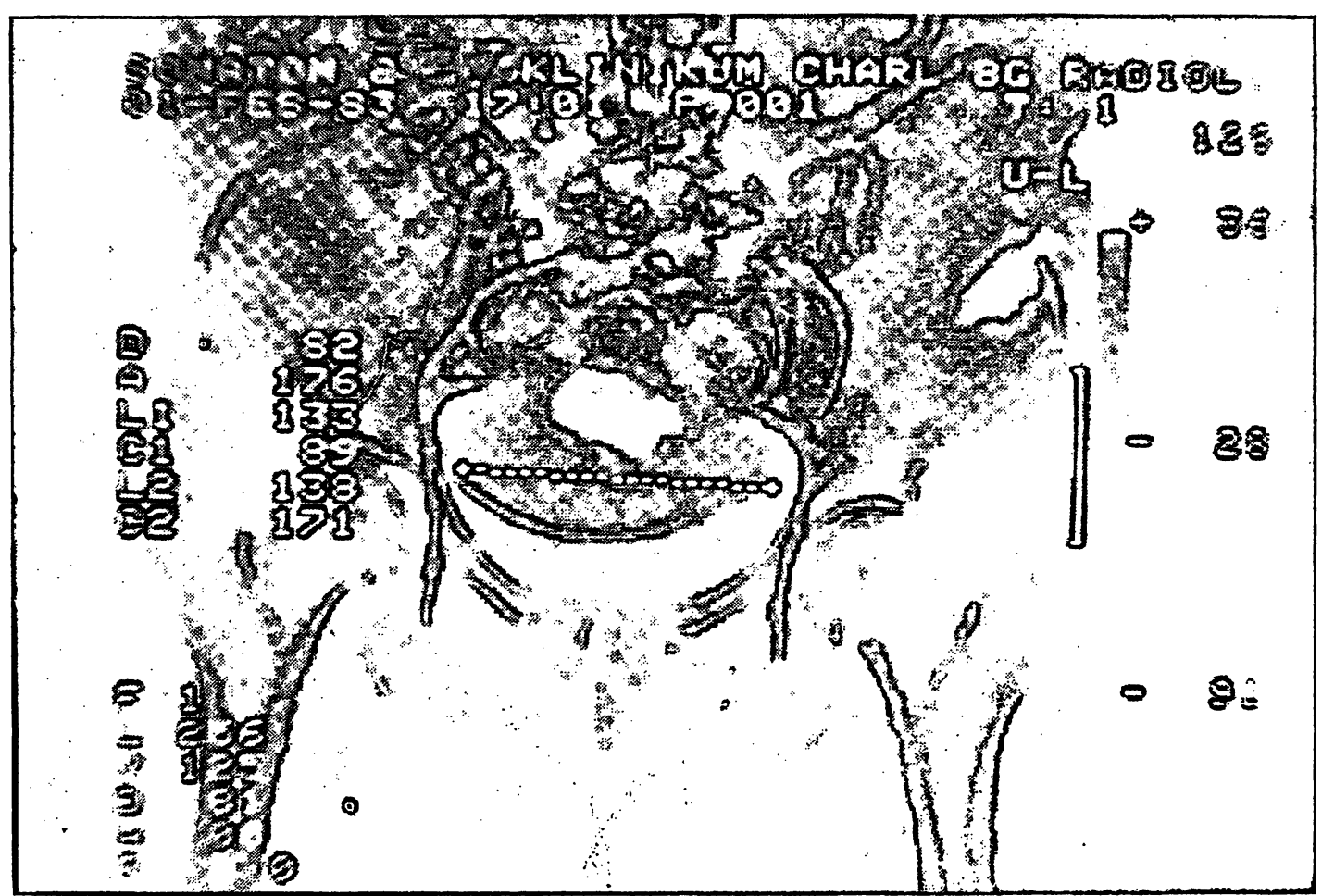

Fig. 3. Interspinous distance. $\mathrm{D}=8.2 \mathrm{~cm}$ (normal $10.5 \mathrm{~cm}$ ). The determination of the real distance yielded the same value as the corrected one. 
(antero-posterior diameter of the pelvic outlet) can be determined at any time, even afterwards, without additional exposure. Statements about the obstetrically important sacral curvature are only indirectly possible.

This technique also depicts the fetal skeleton and thus allows the diagnosis of fetal malformations or abnormal positions of the fetal head (e. g., hyperextension in breech presentation). An additional indication for the topogram are breech presentations and a relative disproportion after a previous operative delivery.

\section{Discussion}

As recently as several years ago there were about 20 indications for pelvic radiography during pregnancy [1]. This has changed since the introduction of sonography. Two reasons caused us to perform x-ray pelvimetry only rarely during the last few years: First, it is well known that knowledge of the dimensions of the bony pelvis allows only an uncertain statement about the subsequent delivery; except for gross deviations from the norm, the size of the fetus and its adaptation for delivery mechanics are the more important parameters. Secondly, the radiation to the fetus in late pregnancy has a small but potential risk of somatic or genetic damage $[5,10]$. Radiation exposure should not exceed $1 \mathrm{rad}\left(10^{-2} \mathrm{~Gy}\right)$ during pregnancy [8]. The gonad dose for conventional radiography during pregnancy is dependent on technique and is assumed to be between $150 \mathrm{mrad}(1.5 \times$ $\left.10^{-3} \mathrm{~Gy}\right)$ [11] and $885 \mathrm{mrad}\left(8.85 \times 10^{-3} \mathrm{~Gy}\right)$ [7].

Because the radiation dose with digital radiography is only $15 \%$ of that of conventional $x-$

\section{Summary}

Sonography is firmly established in obstetrics as the method of choice for the localization of fetus and placenta. However, for the determination of pelvic dimensions sonography does not suffice. Thus, for a few strictly selected indications conventional $\mathrm{x}$-ray pelvimetry is used. This has the disadvantage of the relatively high radiation dose for the fetus and the ray pelvimetry we see a renewed possibility for pelvimetry.

\section{Conclusion}

Digital radiography in comparison to conventional radiographic technique has the following advantages [4]:

1. Very low exposure of the body to ionizing radiation. Because the detectors practically absorb all the emitted and penetrating rays only a low entry dose is required.

2. Extremely low scatter radiation because of the collimation of the beam to $1.5 \mathrm{~mm}$ width and favorable tube and dectector distances to the patient.

3. High contrast resolution.

4. Direct readout of the distance between two points.

5. Simple electronic image manipulation (measurement of absorption values and others) and data storage.

6. Avoidance of erroneous exposures.

Digital radiography has the following disadvantages when compared to conventional radiography.

1. Poor spacial resolution.

2. Poor image quality in obese patients for lateral images because of insufficient numbers of photons. This cannot be compensated for by altering the output of the x-ray tube.

We conclude that digital radiography is an exact and simple method with a low radiation dose which may replace conventional radiography for x-ray pelvimetry.

maternal gonads. Since the introduction of digital radiography, there is the alternative of digital pelvimetry. We performed dosimetry comparing digital and conventional radiography with the new high amplifying screens (Quanta III, Dupont) "using an ionization dosimeter and a wax phantom. The radiation dose of digital radiography was $24 \mu \mathrm{Gy}$. This corresponds to about 
$15 \%$ of a comparable conventional exposure (177 $\mu \mathrm{Gy})$. A further advantage of digital radiography is a standardized and rapid exposure technique; furthermore pelvic dimensions can be measured directly.
The disadvantages are the poorer spacial resolution and poor image quality in obese patients. Digital radiography because of its lower radiation dose is suitable for pelvimetry for special indications.

Keywords: Computer tomography, digital radiography, dosimetry, high amplifying film-screen combinations, pelvimetry, radiation dose.

\section{Zusammenfassung}

Pelvimetrie mit Hilfe der digitalen Radiographie unter besonderer Berücksichtigung der Strahlendosis Die Sonographie hat sich in der Geburtshilfe als Methode der Wahl zur Lokalisation von Fötus und Placenta fest etabliert. Zur Bestimmung der Beckenmaße ergibt die Ultraschalluntersuchung aber keine ausreichenden Ergebnisse, daher wurde bisher bei wenigen streng ausgewählten Indikationen eine konventionelle Röntgenpelvimetrie durchgeführt. Nachteilig ist hier die relativ hohe Strahlenbelastung des Feten und der mütterlichen Gonaden. Mit der Einführung der digitalen Radiographie besteht jetzt die Alternative einer digitalen Pelvimetrie. Dosismessungen wurden deshalb zum Vergleich bei der digitalen Radiographie und konventionellem Röntgen mit neuentwickelten hochverstärkten Folien (Quanta
III, Dupont) vorgenommen. Verwendet wurde ein Ionisationsdosimeter und ein Wachsphantom. Die Strahlenbelastung der digitalen Radiographie betrug $24 \mu \mathrm{Gy}$. Das entspricht etwa $15 \%$ einer vergleichbaren konventionellen Aufnahme (177 $\mu \mathrm{Gy})$. Als weiterer Vorteil der digitalen Radiographie ist der standardisierte und schnelle Aufnahmemodus anzusehen, weiterhin können die Bekkenmaße direkt bestimmt werden.

Nachteilig sind ein geringeres räumliches Auflösungsvermögen der digitalen Radiographie und die eingeschränkte Bildqualität bei adipösen Patientinnen. Insbesondere wegen der geringen Strahlenbelastung bietet sich die digitale Radiographie zur Pelvimetrie bei Problemfällen an.

Schlüsselwörter: Computertomographie, digitale Radiographie, Dosismessung, hochverstärkende Film-Folienkombination, Pelvimetrie, Strahlenbelastung.

\section{Résumé}

Pelvimétrie par radiographie digitale - dosimétrie L'échographie a solidement établi sa place en obstétrique comme la méthode de choix pour la localisation du fœtus et du placenta. Cependant, l'échographie n'est pas suffisante pour déterminer les dimensions du bassin. C'est ainsi que l'on effectue des radiopelvimétries conventionnelles dans quelques indications strictement sélectionnées. Cette attitude offre le désavantage d'une irradiation relativement élevée pour le fœus et les gonades maternelles. Depuis l'introduction des radiographies digitales, la pelvimétrie digitale offre une alternative. Nous avons réalisé des dosimétries en comparant radiographie digitale et radiographie conventionelle avec les nouveaux écrans à haut pouvoir d'amplification (quanta
III, Dupont) en se servant de dosimétrie à ionisation et de fantômes de cire. La dose d'irradiation de la radiographie digitale est de 24 micro Gy. Cela correspond au taux de quinze pour cent d'une radiographie conventionelle comparable (177 micro Gy). Un autre avantage de la radiographie digitale est sa technique standardisée et d'exposition rapide; bien plus, les dimensions pelviennes peuvent être mesurées directement.

Les inconvénients en sont la pauvre résolution dans l'espace et la mauvaise qualité des images chez les patientes obèses. La radiographie digitale en raison de sa faible dose d'irradiation est adéquate pour la radiopelvimétrie pour des indications spéciales.

Mots-clés: Couple film écran à haute sensibilité, dose d'irradiation, dosimétrie, pelvimétrie, radiographie digitale, tomographie computérisée.

\section{Bibliography}

[1] Bean, J., B. A. Rodan: Pelvimetry Revisted. Semin. Roentgenol. 17 (1982) 164

[2] Federle, M. P., H. A. Cohen, M. F. Rosenwein, M. N. Brant-Zawadzki, C. E. CanN: Pelvimetry by Digital Radiography: A Low-Dose Examination. Radiology 143 (1982) 733
[3] Freyschmidt, J., D. SAure, W. Ujak, F. Nüsslin: Zum Problem der Dosiseinsparung durch Einsatz hochverstärkender Seltene-Erden-Folien oder durch Erhöhung der Aufnahmespannung. Fortschr. Roentgenstr. 129, 1 (1978) 113 
[4] HÜBENER, K. H.: Digitale Radiographie-Möglichkeiten und Perspektiven einer neuen radiologischen Technik. Habilitationsschrift 1980

[5] MacMahon, B.: Prenatal x-ray exposure and childhood cancer. JNCI 28 (1962) 1173

[6] Meydam, K., M. Römer, K. G. Hering: Dosismessung an Patientinnen mit der Rastermammographie. Roentgenpraxis 36 (1983) 237

[7] OsBoRn, S. B.: Variations in the radiation dose received by the patient in diagnostic radiology. Br. J. Radiol. 36 (1963) 230

[8] Reekie, D., M. Davison, J. K. Davidson: The radiation hazard in radiography of the female abdomen and pelvis. Br. J. Radiol. 40 (1967) 849

[9] ReITHER, M., P. BROZIK, B. SCHORN: Dosismessung bei Ausscheidungsurographien im Kindesalter unter Verwendung einer neuen Film-Folien-Kombination. Roentgenpraxis 36 (1983) 170

[10] STEWARD, A., G. W. KNEALE: Radiation dose effects in relation to obstetric $\mathrm{x}$-ray and childhood cancer. Lancet 1 (1970) 1185
[11] United Nations SCIENTIFIC COMmitTeE ON THE EFFECTS OF ATOMIC RADIATION (UNSCEAR): Sources and effects of ionizing radiation, report to the General Assembly, with annexes United Nations, New York 1977

[12] SzoKe, B., D. KIss: Ultrahang pelvimetria jelentösége a szülézetben. Orv. Hetil. 118 (1977) 1233

[13] VAClavinkova, V.: Ultrasonic Pelvimetry. A method for preliminary estimation of the pelvic outlet. Ultrasonics 14 (1976) 133

Received April 19, 1984. Revised August 30, 1984. Accepted September 10, 1984.

Priv.-Doz. Dr. C. Claussen Univ.-Klinikum Charlottenburg Abt. Radiologie Spandauer Damm 130 1000 Berlin 19, Fed. Rep. Germany 